\title{
Divergent Effects of Tissue Inhibitor of Metalloproteinase-1, -2, or -3 Overexpression on Rat Vascular Smooth Muscle Cell Invasion, Proliferation, and Death In Vitro
}

\author{
TIMP-3 Promotes Apoptosis
}

\author{
Andrew H. Baker, Alla B. Zaltsman, Sarah J. George, and Andrew C. Newby \\ Bristol Heart Institute, University of Bristol, Bristol Royal Infirmary, Marlborough Road, Bristol BS2 8HW, United Kingdom
}

\begin{abstract}
Tissue inhibitors of metalloproteinases (TIMPs) are a family of closely related secreted proteins that limit matrix metalloproteinase (MMP) activity and also have direct effects on cell growth. We used the highly efficient adenoviral delivery system to overexpress individual TIMPs from the cytomegalovirus immediate early promoter in rat aortic smooth muscle cells. Overexpression of TIMP-1, -2 , or -3 , or a synthetic MMP inhibitor similarly inhibited SMC chemotaxis and invasion through reconstituted basement membrane. TIMP-1 overexpression did not effect cell proliferation. By contrast, TIMP- 2 caused a dose-dependent reduction in proliferation, an effect not mimicked by a synthetic MMP inhibitor. TIMP-3 overexpression induced DNA synthesis, and promoted SMC death by apoptosis, a phenotype reproduced by adding TIMP-3 to uninfected cells, but not by a synthetic MMP inhibitor. Our study is the first to compare systematically the effect of overexpression of three TIMPs in any cell. We found similar effects on invasion mediated by inhibition of MMP activity, but widely divergent effects on proliferation and death through actions of TIMP-2 and -3 independent of MMP inhibition. These findings have important implications for the physiological roles of TIMPs and their use in gene therapy. (J. Clin. Invest. 1998. 101:1478-1487.) Key words: adenovirus • tissue inhibitor of metalloproteinase - gene therapy - apoptosis • smooth muscle cell
\end{abstract}

\section{Introduction}

Involvement of smooth muscle cell $(\mathrm{SMC})^{1}$ proliferation and migration during neointima formation in atherosclerosis, restenosis after coronary angioplasty, and late vein graft failure is well-established. Intense research has therefore focused on the molecular mechanisms involved with the goal of devising pharmacological or gene-based therapy.

Address correspondence to Dr. Andrew H. Baker, Bristol Heart Institute, Bristol Royal Infirmary, Marlborough Road, Bristol BS2 8HW, United Kingdom. Phone: +44-1179-283586/8; FAX: +44-1179283581; E-mail: A.H.Baker@bris.ac.uk

Received for publication 22 August 1997 and accepted in revised form 13 January 1998.

J. Clin. Invest.

(C) The American Society for Clinical Investigation, Inc. 0021-9738/98/03/1478/10 \$2.00

Volume 101, Number 6, March 1998, 1478-1487

http://www.jci.org
Recent attention has focused on the role played by extracellular matrix components in maintaining SMC quiescence, and its reversal by the matrix-degrading metalloproteinases (MMPs). The MMPs consist of a large family of enzymes that together can digest all components of the extracellular matrix at neutral $\mathrm{pH}$ (1). Basement membrane-degrading MMPs promote the ability of SMC both to proliferate and migrate as shown by inhibitor studies in vitro $(2,3,4)$ and in vivo $(5,6)$. Furthermore, upregulation of MMP-2 and -9 has been identified in arteries after balloon injury $(7,8)$, vein grafts $(9)$, and in atherosclerotic plaques $(10,11)$. Control of MMP activity is provided by transcription regulation, latent proform activation, and by binding of pro and active forms to tissue inhibitor of metalloproteinases (TIMPs), proteins that are also secreted into the extracellular matrix. The family of TIMPs consists of four members (12-15). TIMPs-1, -2 , and -4 are secreted as soluble proteins, whereas TIMP-3 is associated with the matrix components as an insoluble protein (16). Binding of each of the TIMPs to the catalytic site of the activated forms of the secreted MMPs leads to inhibition $(17,18)$. In addition, binding of specific TIMPs to the COOH-terminal hemopexin-like domain of some MMPs regulates activation of the proforms. TIMP-1 binds and slows activation of the latent proform of MMP-9, while TIMP-2 binds and regulates activation of proMMP-2 (18-21). At low concentrations, TIMP-2 promotes ternary complex formation with proMMP-2 and cell surface membrane-type metalloproteinases (MT-MMPs). This formation results in inactivation of MT1-MMP, but the proMMP-2 present in the complex can be proteolytically processed to active MMP-2 by a second molecule of MT1-MMP provided that it is free of TIMP-2. Hence, low concentrations of TIMP-2 promote MMP-2 acivation, but higher molar ratios of TIMP-2 actually inhibit MMP-2 activation $(22,23)$. Oddly, TIMP-1, in contrast to TIMP-2, does not inhibit MT1-MMP (24).

While most of the cell biological effects of TIMPs are believed to be mediated indirectly by inhibition of MMPs, direct growth-promoting (25) and inhibitory (26) effects of TIMP-2 have been described.

Given the established role for MMPs in neointima formation, one approach to therapy may be to overexpress TIMPs. As an initial step in this development, we have used recombinant adenoviruses selectively and specifically to overexpress individual TIMPs in isolated cultures of rat SMC. We observed similar effects of the three TIMPs on invasion through artifi-

1. Abbreviations used in this paper: $\mathrm{BrdU}$, bromodeoxyuridine; ISEL, in situ end labeling; MMP, matrix metalloproteinase; MT, membrane-type; pfu, plaque-forming units; SMC, smooth muscle cell; TIMP, tissue inhibitor of metalloproteinase; TUNEL, terminal dUTP nick end labeling. 
cial basement membrane, but widely divergent effects on proliferation and death.

\section{Methods}

\section{Materials}

Human kidney embryonic 293 cells were purchased from Microbix (Toronto, Canada) and Hela cells from the European Collection of Animal Cell Cultures (Salisbury, United Kingdom). All chemicals, unless otherwise stated, were obtained from Sigma Chemical Co. (Poole, United Kingdom), and were of the highest grade available. Culture media and additives were obtained from GIBCO BRL (Paisley, Scotland). The mouse monoclonal anti-TIMP-3 antibody was generously provided by Dr. Iwata (Fuji Chemicals, Toyama, Japan) and the human TIMP-3 standard was a gift from Dr. G. Murphy (Strangeways Research Labs, Cambridge, United Kingdom). The adenovirus E1a antibody was purchased from Calbiochem-Novabiochem (UK) Ltd. (Nottingham, United Kingdom).

\section{Methods}

Cell culture. 293 cells (27) were maintained in MEM supplemented with $100 \mathrm{U} / \mathrm{ml}$ penicillin, $100 \mu \mathrm{g} / \mathrm{ml}$ streptomycin, and $10 \%$ ( $\mathrm{vol} / \mathrm{vol}$ ) FCS. Rat SMC were prepared from thoracic aortas as described previously (28), and were cultured in DMEM supplemented with $10 \%$ (vol/vol) FCS, $100 \mathrm{U} / \mathrm{ml}$ penicillin, $100 \mu \mathrm{g} / \mathrm{ml}$ streptomycin, and used between passages 3 and 10. SMC were identified by immunostaining for alpha-SMC actin. All cells were maintained at $37^{\circ} \mathrm{C}$ under a mixture of $95 \%$ air and $5 \% \mathrm{CO}_{2}$. Hela cells were maintained as for SMC.

Adenoviral constructs. The adenovirus RAd35 expresses the bacterial lac Z gene from the cytomegalovirus major immediate early promoter (CMV IEP; 29). RAd66 (gift from G.W.G. Wilkinson, Cardiff, United Kingdom) contains the CMV IEP and polyadenylation signal, but does not express a transgene after infection. The generation and characterization of RAdTIMP-1 and RAdTIMP-2 have been described in detail elsewhere (30).

For generation of RAdTIMP-3, PCR was used to facilitate cloning. Oligonucleotide primers were designed spanning the translational initiation and termination codons based on the published sequences (TIMP-3 sense 5'CAGCAGCGGCAATGACCCCTTG 3', antisense $5^{\prime}$ TCTGGCGCTCAGGGGTCTGTGG 3'; 14). A Nhe I site and clamp was synthesized at the $5^{\prime}$ end of each primer to create unique NheI cloning sites (5' CCTAGCTAGC $3^{\prime}$ ). $0.1 \mathrm{ng}$ of plasmid DNA (generously provided by C. Lopez-Otin, University of Oviedo, Spain) was amplified in a reaction containing $500 \mathrm{ng}$ of sense and antisense primer, $400 \mu \mathrm{M}$ of each dNTP, $2 \mathrm{U}$ of Vent DNA polymerase (New England Biolabs Inc., Beverly, MA) in $10 \mathrm{mM} \mathrm{KCl}, 10 \mathrm{mM}$ $\left(\mathrm{NH}_{2}\right) \mathrm{SO}_{4}, 20 \mathrm{mM}$ Tris $\mathrm{HCl}(\mathrm{pH} 8.8), 2 \mathrm{mM} \mathrm{MgSO}_{4}$, and $0.1 \%$ Triton-X-100. Amplification reactions were performed using a DNA thermocycler (Perkin-Elmer Cetus Instruments, Emeryville, CA). After digestion of PCR products with Nhe I and purification using Wizard PCR preps (Promega, Southampton, United Kingdom), fragments were cloned into the Nhe I site of pAL119 to create pAL119TIMP-3. Orientation of the insert within the vector was assessed by diagnostic restriction enzyme analysis. The entire insert was sequenced using the Sanger dideoxy chain termination method (31) to ensure that no PCR-induced mutations were present. Sequencing primers were located in the cytomegalovirus immediate early promoter (5' CGCCATCCACGCTGTTTTGA $3^{\prime}$ ) and the polyadenylation region (5' TTGAGTAGGATTACAGAGTA 3'). Recombinant adenovirus was generated by cotransfection of pAL119TIMP-3 and pJM17 (32) into low-passage 293 cells. Adenovirus recombinants were plaque-purified, propagated on 293 cells, caesium chloridebanded, and titered using standard assays.

Adenoviral infection protocol. Rat SMC were plated into six-well plates at $\sim 1 \times 10^{5}$ cells/well and left in complete media for $24 \mathrm{~h}$. Immediately before infection, triplicate wells were trypsinized and counted for an accurate cell count. Cells in the remaining wells were infected at the required moi in $2 \mathrm{ml}$ fresh complete media and left for $18 \mathrm{~h}$. Media were removed, and the cells were washed and left in $2 \mathrm{ml}$ fresh complete medium until the required time point. For some assays, cells were grown on glass coverslips placed in six-well plates under identical conditions.

Western blot analysis for TIMP-3. To allow analysis of TIMP-3 levels in cell-associated and conditioned media fractions, cells were washed after infection and maintained for $24 \mathrm{~h}$ in reduced serum media (optiMEM; GIBCO BRL, Paisley, Scotland). Conditioned media were collected and concentrated using centricon-10 filter units (Amicon, Inc., Stonehouse, United Kingdom). Total cell/extracellular matrix lysates were prepared by solubilization in $250 \mu \mathrm{l}$ of $1 \times$ reducing Laemmli buffer (33). Immunoreactive proteins were visualized after western blotting using the ECL system (Amersham International, Little Chalfont, United Kingdom). Bands were quantified using a GS 690 Image Analysis software system (Biorad Laboratories, Hertfordshire, United Kingdom), and band intensities were compared with standard purified recombinant human TIMP-3 protein (75 ng/lane). Western blot analysis for WAF1 was performed using the mouse monoclonal antibody, clone 22 (Oncogene Research Products, Cambridge, United Kingdom).

Detection of functional TIMP production by reverse zymography. Detection of functional TIMP-1 and -2 production from the conditioned media of RAdTIMP-1 and RAdTIMP-2 infected cells, and from the cell/matrix lysate from RAdTIMP-3 infected cells was determined using reverse zymography as described $(19,34)$ using 4-aminophenylmercuric acetate-treated conditioned media from phorbol ester-stimulated rabbit dermal fibroblasts as a source of activated MMPs. After electrophoresis, gels were stained with $0.1 \%$ Coomassie brilliant blue, and TIMP activity was visualized as zones of gelatinase inhibition against a partially digested background of gelatin.

Quantification of TIMP-1 and -2 secretion by ELISA. Secretion of TIMP-1 and - 2 into the conditioned media from uninfected and infected cells was quantified using ELISA assays according to the manufacturer's recommendations (Amersham International). Conditioned media samples were diluted appropriately to fall within the standard range of the assay. For TIMP-1, the assay does not recognize the endogenous rat TIMP-1 protein (28), thus allowing determination of transgene production alone. The TIMP-2 ELISA does recognize the endogenous rat TIMP-2 protein, and values reported for infected samples include the endogenous rat TIMP-2 protein level.

Matrigel invasion assay. Rat SMC were infected with 100 or 300 plaque-forming units/cell (pfu/cell) of adenovirus for $18 \mathrm{~h}$, washed, and left in complete media for $24 \mathrm{~h}$. Cells were trypsinized and washed extensively with DMEM/1\% BSA. $1 \times 10^{5}$ cells were placed in the upper chamber of $8-\mu \mathrm{m}$ pore size 24 -well plate invasion chambers precoated with $50 \mu \mathrm{g}$ of reconstituted basement membrane (Stratech, Luton, United Kingdom). DMEM containing 10\% FCS (chemoattractant) was placed in the lower chamber, and cells were left for $24 \mathrm{~h}$. After $24 \mathrm{~h}$, the conditioned media in the upper chamber was collected and stored at $-20^{\circ} \mathrm{C}$, the cells on the upper surface were removed by gentle abrasion with a cotton bud, and the cells on the underside (invaded) were fixed in methanol and counterstained with hematoxylin. Four random $400 \times$ fields were counted per section. Each sample was performed in triplicate. Data are presented as number of invaded cells $/ 400 \times$ field.

Analysis of cell number. At the required time point, cells were trypsinized and mixed $1: 1$ with $0.2 \%$ trypan blue in PBS, and viable cells were counted using a hemacytometer.

In situ end labeling (ISEL) of DNA. Rat SMC were grown on glass coverslips and fixed in methanol $42 \mathrm{~h}$ after infection initiation. After air drying, cells were washed twice in $1 \times \mathrm{TE}(10 \mathrm{mM}$ Tris $\mathrm{HCl}, \mathrm{pH}$ 8.0, $1 \mathrm{mM}$ EDTA) and incubated in labeling mix (50 mM Tris $\mathrm{HCl}$, $\mathrm{pH} 7.2,10 \mathrm{mM} \mathrm{MgSO}_{4}, 0.1 \mathrm{mM}$ dithiothreitol, $0.01 \mathrm{mM}$ dATP, dCTP, dGTP, $0.01 \mathrm{mM}$ biotin-dUTP, and $8 \mathrm{U} / \mathrm{ml}$ of DNA polymerase I; Klenow) for $15 \mathrm{~min}$ at room temperature. Cells were rinsed in $1 \times \mathrm{TE}$, and endogenous peroxidase was inhibited by incubation in $2 \% \mathrm{H}_{2} \mathrm{O}_{2}$ for $5 \mathrm{~min}$. After further washing, biotin was labeled with Extravidin ${ }^{\mathrm{TM}}$ 
peroxidase (1:200 dilution) in 10\% FCS/PBS. Incubation in diaminobenzidine and subsequent counterstaining with hematoxylin was used to distinguish positive nicked DNA from negative DNA.

Flow cytometric analysis of DNA content. Adherent rat SMC were trypsinized and pooled with any nonadherent cells in the culture, centrifuged, and resuspended in $200 \mu \mathrm{l}$ of PBS. Cells were fixed by adding $2 \mathrm{ml}$ of ice-cold $70 \%$ ethanol while vortexing, and left at $4^{\circ} \mathrm{C}$ before analysis. For staining, cells were recentrifuged and resuspended in $800 \mu \mathrm{l}$ of PBS, and $100 \mu \mathrm{l}$ of $1 \mathrm{mg} / \mathrm{ml}$ RNAse A and $100 \mu \mathrm{l}$ of $0.4 \mathrm{mg} / \mathrm{ml}$ propidium iodide was added and left at room temperature for $30 \mathrm{~min}$. Cells were analyzed on a FACScan (fitted with Cellquest software (Becton Dickinson, San Jose, CA), and data was analyzed using winMDI and Multicycle software packages (Phoenix Flow Systems, San Diego, CA).

Analysis of bromodeoxyuridine (BrdU) incorporation. At the required time point, $10 \mu \mathrm{M} \mathrm{BrdU}$ was added to the media for $4 \mathrm{~h}$, and the cells were fixed in $4 \%$ paraformaldehyde. Cells were blocked in $1 \%$ BSA and $10 \%$ normal goat serum in PBS for $1 \mathrm{~h}$ at $37^{\circ} \mathrm{C}$, and were incubated in primary antibody (mouse monoclonal anti-BrdU 1:600 dilution) overnight at $4^{\circ} \mathrm{C}$. After incubation with an antimouse biotin conjugate (1:200 dilution in 1\% BSA), cells were incubated in streptavidin-HRP (Extravidin ${ }^{\mathrm{TM}}$; Sigma Chemical Co., Poole, United Kingdom). Cells were counterstained in hematoxylin. For counting, $4 \times 200$ fields were counted per slide, and each incubation was performed in triplicate. Results are expressed as percentage BrdU positivity.

Statistical analysis. All data were analyzed using an unpaired Student's $t$ test, and are shown as the mean value \pm SEM.

\section{Results}

Infection by recombinant adenoviruses. Plaque pure recombinant adenoviruses were replication-deficient when tested by plaque titration on nonpermissive Hela cells. Additionally, Hela cells infected with $80 \mathrm{pfu} / \mathrm{cell}$ of each adenovirus lacked E1A when tested by indirect immunofluoresence using an anti-E1A antibody and 293 cells as a positive control (all data not shown).

Rat SMC were dose-dependently and efficiently infected with RAd35 at 30,100, and 300 pfu/cell $(8 \pm 1 \%, 24 \pm 2 \%$ and $67 \pm 2 \%$, respectively). Infection with control adenoviruses or TIMP-expressing adenoviruses had no effect on synthesis of MMP-2 or -9 by SMC in vitro (30).

Measurement of recombinant TIMP protein production. Functional recombinant protein production from RAdTIMP-1 and -2-infected cells has been described in detail elsewhere (30). Using a similar approach, TIMP-3 production from RAdTIMP-3-infected cells was visualized by immunofluorescence (not shown) and quantified by Western blotting (Fig. 1, Table I), and functional integrity was confirmed by reverse zymography (not shown). Uninfected and RAd66-infected cultures demonstrated low-level production of endogenous TIMP-3, representing fully glycosylated TIMP-3 (Fig. 1, Table I). No TIMP-3 was detected in conditioned media from uninfected or RAd66-infected cultures. RAdTIMP-3 infection resulted in dose-dependent induction of TIMP-3 both in the total cell lysate and in conditioned media, although much higher levels were observed in cell/matrix lysates (Fig. 1). Both the unglycosylated and glycosylated forms were detected for cell lysates and conditioned media samples, although the majority of the RAdTIMP-3-induced elevation of TIMP-3 was in the unglycosylated form. Reverse zymography (not shown) confirmed that the recombinant TIMP-3 was mainly unglycosylated and functionally active.

\section{CELL/MATRIX}

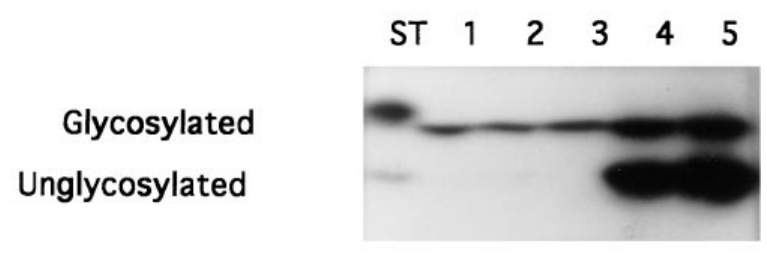

\section{CONDITIONED MEDIA}

\author{
Glycosylated \\ Unglycosylated
}

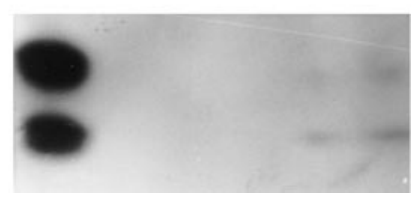

Figure 1. Western blot analysis for recombinant TIMP-3 production. Western blot analysis of cell/matrix lysates and conditioned media isolated from SMC $66 \mathrm{~h}$ after infection. (1) Uninfected control, (2) RAd66 100 pfu/cell, (3) RAd66 300 pfu/cell, (4) RAdTIMP-3 100 pfu/ cell, (5) RAdTIMP-3 300 pfu/cell. $S T$, purified recombinant TIMP-3 (75 ng).

The levels of secretion of TIMPs into the conditioned and extracellular matrix were quantified by ELISA or Western blotting, and are summarized in Table I. No significant effect of RAd66 infection on TIMP production was observed (Table I). A dose-dependent increase in TIMP-1, -2, and -3 levels was detected in cultures infected with 30,100 , and $300 \mathrm{pfu} / \mathrm{cell}$ of RAdTIMPs (Table I).

Effect of RAd TIMPs on rat SMC invasion through basement membrane. To determine the effect of overexpressing individual TIMPs on the invasion of rat SMC through reconstituted basement membrane, modified Boyden chamber assays were performed. Infection of SMC with recombinant adenoviruses had no significant effect on the adherence of cells to

Table I. Quantification of Recombinant TIMP Secretion from Infected Cells

\begin{tabular}{lcccc}
\hline \multicolumn{1}{c}{ Sample } & moi & TIMP-1 & TIMP-2 & TIMP-3 \\
\hline & & & $n g / m l$ & \\
Uninfected & & 0 & $154 \pm 8$ & 138 \\
RAd66 & $300 \mathrm{pfu} / \mathrm{cell}$ & 0 & $164 \pm 4$ & 233 \\
RAdTIMP-1 & $30 \mathrm{pfu} / \mathrm{cell}$ & $63 \pm 8$ & $\mathrm{ND}$ & $\mathrm{ND}$ \\
& $100 \mathrm{pfu} / \mathrm{cell}$ & $590 \pm 70$ & $\mathrm{ND}$ & $\mathrm{ND}$ \\
& $300 \mathrm{pfu} / \mathrm{cell}$ & $2800 \pm 290$ & $\mathrm{ND}$ & $\mathrm{ND}$ \\
& $30 \mathrm{pfu} / \mathrm{cell}$ & $\mathrm{ND}$ & $293 \pm 9$ & $\mathrm{ND}$ \\
RAdTIMP-2 & $100 \mathrm{pfu} / \mathrm{cell}$ & $\mathrm{ND}$ & $560 \pm 25$ & $\mathrm{ND}$ \\
& $300 \mathrm{pfu} / \mathrm{cell}$ & $\mathrm{ND}$ & $3460 \pm 90$ & $\mathrm{ND}$ \\
& $100 \mathrm{pfu} / \mathrm{cell}$ & $\mathrm{ND}$ & $\mathrm{ND}$ & 1780 \\
RAdTIMP-3 & $300 \mathrm{pfu} / \mathrm{cell}$ & $\mathrm{ND}$ & $\mathrm{ND}$ & 2120 \\
& & & & \\
\hline
\end{tabular}

TIMP-1 and - 2 levels in conditioned media collected $90 \mathrm{~h}$ after infection were detected using ELISA assays. TIMP-3 levels in cell/matrix lysates and conditioned media were detected $66 \mathrm{~h}$ after infection using Western blot analysis (total amount shown) using a human recombinant TIMP-3 standard. The TIMP-1 ELISA does not cross-react with the endogenous rat TIMP-1 protein, whereas the TIMP-2 ELISA does. The TIMP-3 antibody detects the rat TIMP-3 protein. ND, not determined. 
A

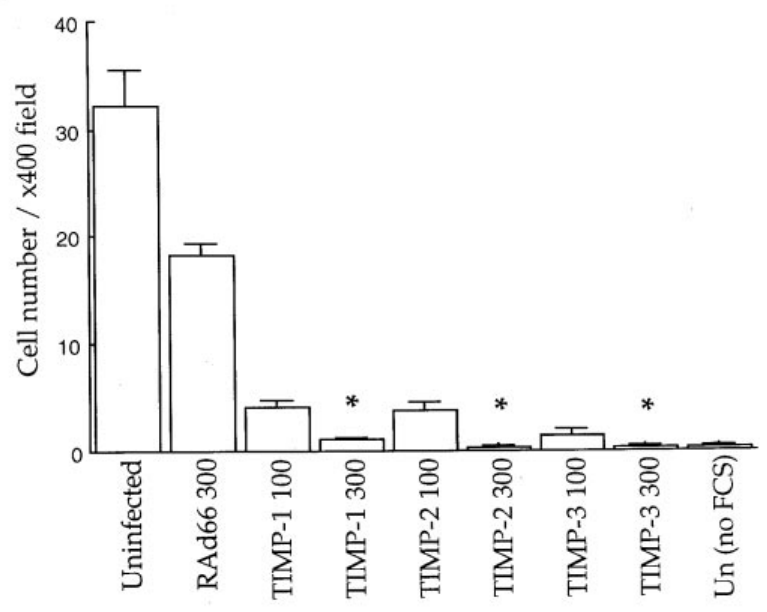

B

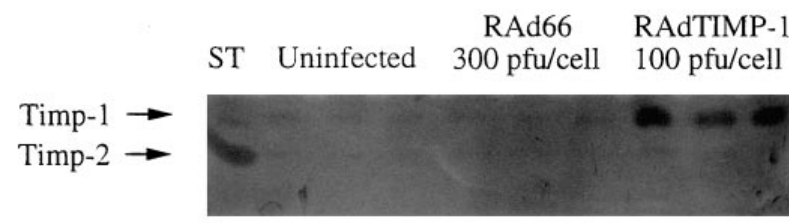

RAdTIMP-1 RAdTIMP-2 RAdTIMP-2 $300 \mathrm{pfu} / \mathrm{cell} \quad 100 \mathrm{pfu} / \mathrm{cell} \quad 300 \mathrm{pfu} / \mathrm{cell}$

Timp-1 $\rightarrow$ Timp-2 $\rightarrow$

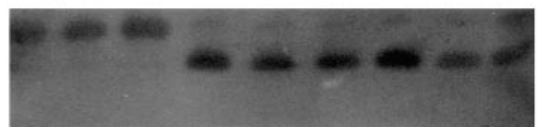

Figure 2. Effect of RAdTIMPs on rat SMC invasion through reconstituted basement membrane. SMC were infected with recombinant adenoviruses and analyzed for invasion using modified Boyden chambers. (A) Invaded cells were counted on the underside of Matrigel-coated filters after hematoxylin counterstaining. Samples were performed in triplicate, and $4 \times 400$ fields/section were counted. *Statistical significance for infection at $300 \mathrm{pfu} / \mathrm{cell}$ compared with RAd66-infected cells $(P<0.05)$. (B) $10-\mu l$ aliquots of conditioned media samples from the upper chamber of uninfected, RAd66infected (300 pfu/cell), and RAdTIMP-1- and -2-infected samples were analyzed by reverse zymography for secreted TIMP activity. The running positions of TIMP- 1 and -2 standards are indicated. These data are representative of two experiments.

matrigel (not shown). Although infection with RAd66 partially inhibited invasion per se, overexpression of TIMP-1, -2 , or -3 resulted in an additional profound dose-dependent inhibition (Fig. $2 \mathrm{~A}$ ) similar to the level of inhibition observed using $10 \mu \mathrm{M}$ of synthetic MMP inhibitor Ro-31-9370 (98 $\pm 1 \%$, $n=3 ; 8$ ). High-level functional TIMP-1 and -2 production was detected in the conditioned media collected from the upper chamber of RAdTIMP-1- and -2-infected samples, respectively, using reverse zymography (Fig. $2 \mathrm{~B}$ ). TIMP-3 production could not be determined in the same manner because it remains mainly associated with the extracellular matrix. No increase in TIMP-1 or TIMP-2 levels were observed in RAd66infected cells (Fig. 2 B). To investigate the contribution of effects on chemotaxis to the effects on invasion, migration across uncoated filters was also studied. Infection with RAdTIMP-1, -2 , and -3 partially inhibited chemotaxis by $61 \pm 4,54 \pm 3$, and
$49 \pm 3 \%$, respectively, which was again similar to the inhibition achieved by $10 \mu \mathrm{M}$ of Ro-31-9370 (55 $\pm 5 \%$, all $n=12)$. RAd66 infection did not inhibit chemotaxis $(102 \pm 7 \%)$. These results indicate that inhibition of chemotaxis contributed in part to the effects of TIMP overexpression on invasion.

Effect of RAdTIMPs on rat SMC proliferation. The effect of TIMP overexpression on cell number was determined in exponentially growing cultures. Rat SMC were infected with 30 , 100 , and $300 \mathrm{pfu} / \mathrm{cell}$, and viable adherent cells were counted 42,66 , and $90 \mathrm{~h}$ after infection initiation. No significant effect of RAd66 infection or addition of $10 \mu \mathrm{M}$ Ro-31-9370 (results not shown) on cell number was observed at any time point compared with uninfected cultures (Fig. 3). However, overexpression of individual TIMPs produced divergent effects. TIMP-1 had no significant effect on total cell number at any infection concentration tested when compared with RAd66infected cells (Fig. 3). TIMP-2 and TIMP-3 induced a dosedependent inhibition in the increase in cell number compared with control uninfected or RAd66-infected samples, which was significant (Fig. 3; $P<0.01$ for 100 and 300 pfu/cell compared with RAd66 infected controls). Morphological analysis of infected cultures revealed that while there was no visible loss of cell viability in RAd66, RAdTIMP-1- and RAdTIMP-2treated cultures, cell death was apparent in RAdTIMP-3treated cultures (Fig. 4). Adding the same levels of exogenous TIMP-2 as those achieved by viral infection to SMC cultures did not reduce cell number compared with control cultures (not shown). However, addition of exogenous TIMP-3 to uninfected cells did induce a similar phenotype as that found in RAdTIMP-3-infected cells (see below).

To evaluate the effect of TIMP overexpression on S-phase populations, cells were pulsed for $4 \mathrm{~h}$ with BrdU at either 42 or $66 \mathrm{~h}$ after initiation of adenoviral infection. Adding $10 \mu \mathrm{M}$ Ro31-9370 to uninfected cultures had no effect on BrdU profiles of SMCs (not shown). No effect of RAd66 or RAdTIMP-1 on the percentage of cells labeled with BrdU was observed at either 100 or $300 \mathrm{pfu} / \mathrm{cell}$ compared with uninfected controls (Fig. 5). TIMP-2 overexpression, however, resulted in a significant dose-dependent decrease in the percentage of cells labeled with $\mathrm{BrdU}$ at 100 and $300 \mathrm{pfu} / \mathrm{cell}$ compared with RAd66-infected cultures (Fig. 5; $P<0.05$ ). In contrast, TIMP-3 overexpression resulted in a significant dose dependent increase in the BrdU index (Fig. 5; $P<0.05$ ).

Evaluation of apoptotic cell death induced by TIMP-3. When studied by time lapse microscopy (not shown), morphological features of apoptosis in RAdTIMP-3-infected cells (including cell shrinkage, nuclear chromatin condensation, and membrane blebbing) were apparent (Fig. 4, arrow). As a further indicator of cells undergoing apoptotic cell death, uninfected, RAd66-, RAdTIMP-2-, and RAdTIMP-3-infected cultures were labeled by ISEL $42 \mathrm{~h}$ after initiation of infection. Uninfected cultures, RAd66-, and RAdTIMP-2-infected cultures $(300 \mathrm{pfu} / \mathrm{cell})$ showed very few $(0 \%$ uninfected; $0.2 \%$ RAd66) isolated brown nuclei (Fig. 6, $A$ and $B$; TIMP-2 not shown). By comparison, RAdTIMP-3-infected cultures (300 pfu/cell) showed $27 \pm 2 \%$ of cells with dark brown nuclei and condensed chromatin ( $n=3$; Fig. 6, $C$ and $D)$. Similar results were obtained with the terminal dUTP nick end labeling (TUNEL) technique (not shown). No effect on the percentage of ISEL-positive cells was observed by adding $10 \mu \mathrm{M}$ of Ro31-9370 to either uninfected, RAd66-infected, or RAdTIMP3 -infected cells (not shown). 


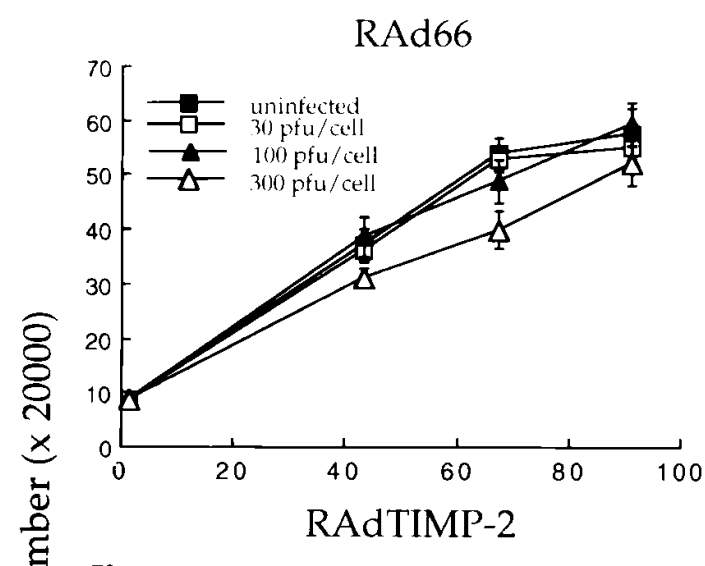

\section{RAdTIMP-1}
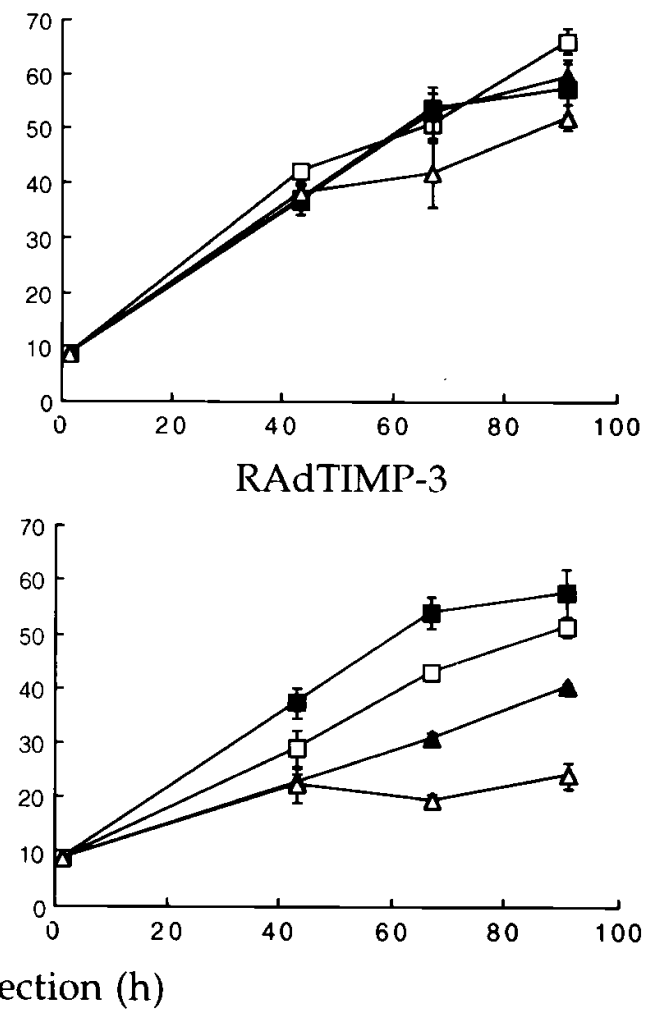

Figure 3. Effect of RAdTIMPs on total cell number. After infections, cells were trypsinized, and viable adherent cells were counted 42, 66, and $90 \mathrm{~h}$ after initiation of infection for analysis of total cell number. These data are representative of three experiments.

We determined whether the effect of RAdTIMP-3 infection could be reproduced by adding recombinant TIMP-3 to uninfected cultures. Recombinant human TIMP-3 added to SMC cultures became associated with the extracellular matrix (Fig $7 \mathrm{~B}$ ), and produced a dose-dependent reduction in cell number compared with controls (Fig. $7 A$ ). TIMP-3-treated cells showed morphological features of apoptosis (Fig $7 C$ ), and became ISEL-positive (Fig. $7 \mathrm{D}$ ).

Flow cytometry was also used to quantify cell death and cell cycle parameters. Infection of cells with RAd66 had no ef-
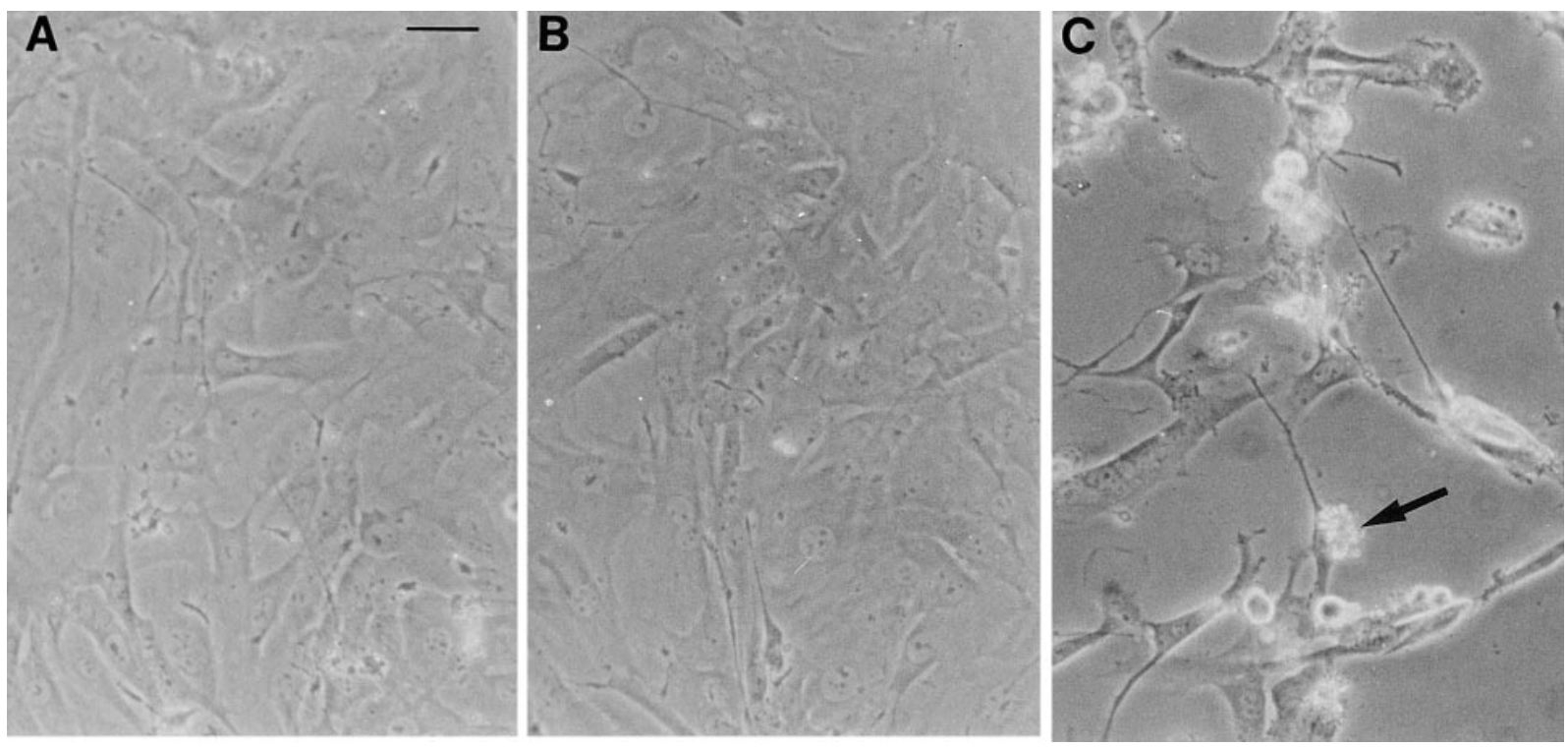

Figure 4. Morphology of infected cells. Phase contrast pictures from $(A)$ uninfected, $(B)$ RAd66-infected (300 pfu/cell), and (C) RAdTIMP3 -infected (300 pfu/cell) cultures taken $66 \mathrm{~h}$ after infection. A cell undergoing apoptosis is indicated with an arrow. Bar, $25 \mu \mathrm{m}$. 


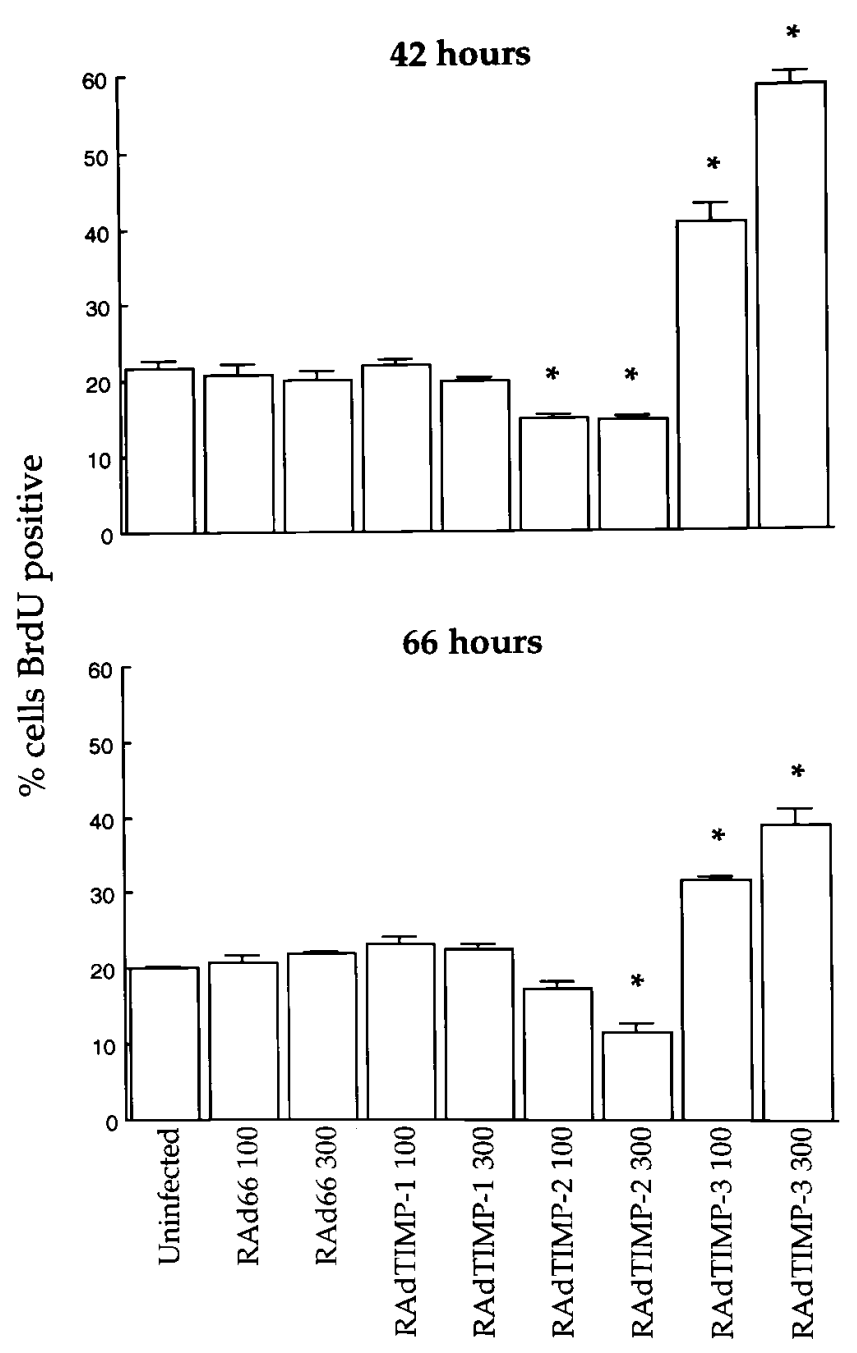

Figure 5. Analysis of BrdU indices. Cells were pulsed for $4 \mathrm{~h}$ with 10 $\mu \mathrm{M} \mathrm{BrdU}$, and the percentage of cells was positively determined by counting $4 \times 200$ fields/section for triplicate cultures. $* P<0.05 \mathrm{com}-$ pared with the RAd66-infected cells at the equivalent pfu/cell. These data are representative of three experiments.

fect on the percentage of cells in $\mathrm{G} 0 / \mathrm{G} 1, \mathrm{~S}$, or $\mathrm{G} 2 / \mathrm{M}$ phases of the cell cycle compared with uninfected controls (Table II). However, infection of cells with RAdTIMP-3 induced dramatic changes in the DNA content profiles (Table II). For cells in cycle, there was a significant reduction in the proportion of cells in G0/G1 (between control or RAd66-infected cells and RAdTIMP-3-infected cells at 42 and $66 \mathrm{~h}$; Table II). There was a corresponding fourfold elevation in the $\mathrm{S}$ phase for RAdTIMP-3-infected cells, and a twofold increase in the G2/M phases (Table II). The percentage of cells in pre-G0 (dying) was elevated fourfold for RAdTIMP-3-infected cells compared with control or RAd66-infected cells at both 42 and $66 \mathrm{~h}$.

To evaluate whether overexpression of TIMP-3 induced deregulation of intracellular cell cycle regulatory mechanisms, we examined whether RAdTIMP-3 infection resulted in induction of WAF1, a protein associated with the cell cycle and apoptosis of SMC. Low-level expression of WAF1 was observed in uninfected and RAd66-infected cells. However, in
Table II. Quantification of Cell Cycle Characteristics of Uninfected and Infected Rat SMC

\begin{tabular}{lllll}
\hline \multicolumn{1}{c}{ Sample } & G0/G1 & \multicolumn{1}{c}{ S } & G2/M & *PreG0 \\
\hline 42 hours & & & & \\
$\quad$ Uninfected & $84 \pm 1$ & $6 \pm 0.5$ & $10 \pm 0.2$ & $2 \pm 0.3$ \\
$\quad$ RAd66 300 pfu/cell & $84 \pm 0.5$ & $6 \pm 0.1$ & $10 \pm 0.3$ & $4 \pm 1$ \\
$\quad$ RAdTIMP-3 300 pfu/cell & $58 \pm 1^{\ddagger}$ & $23 \pm 1^{\ddagger}$ & $19 \pm 1^{\ddagger}$ & $10 \pm 1^{\ddagger}$ \\
66 hours & & & & \\
$\quad$ Uninfected & $79 \pm 0.3$ & $6 \pm 1$ & $15 \pm 1$ & $3 \pm 0.3$ \\
$\quad$ RAd66 300 pfu/cell & $77 \pm 1$ & $7 \pm 0.1$ & $16 \pm 1$ & $4 \pm 1$ \\
$\quad$ RAdTIMP-3 300 pfu/cell & $63 \pm 1^{\ddagger}$ & $17 \pm 1^{\ddagger}$ & $20 \pm 0.1^{\ddagger}$ & $15 \pm 1^{\ddagger}$ \\
& & & & \\
\hline
\end{tabular}

Cells were analyzed by propidium iodide staining and flow cytometric analysis for cell cycle populations after RAd66 and RAdTIMP-3 infection of SMC. *For pre-G0 analysis, data are presented as the percentage of the total gated cell population. For G0/G1, S, and G2M, data are calculated from the percentage of cells in cycle (excluding cells in the preG0 region). ${ }^{\ddagger} P<0.01$ for RAdTIMP-3 vs. uninfected cells and RAd66 infection.

RAdTIMP-3 infected cells, a dose-dependent induction of WAF1 was detected (Fig. 8).

\section{Discussion}

We found that similar levels of TIMP-1, -2 , or -3 overexpression could be achieved using adenoviral gene delivery at similar doses. Overexpression of each TIMP inhibited SMC chemotaxis and invasion through reconstituted basement membrane to a similar extent, and similarly to a synthetic MMP inhibitor. However, while TIMP-1 and synthetic MMP inhibitors had no effect on cell proliferation, TIMP-2 caused a dose-dependent inhibition of cell number increase and BrdU incorporation without affecting cell death. TIMP-3 overexpression also caused a dose-dependent inhibition of the increase in cell number, but paradoxically induced S-phase entry. This paradox was explained by accumulation of cells in the G2/M phase of the cell cycle and death of cells by apoptosis.

Inhibition of rat SMC chemotaxis across uncoated membranes and invasion through reconstituted basement membrane was expected, and confirms and extends previous data for TIMP-1 (35). From our results, TIMP-2 and -3 are approximately equipotent with TIMP-1. Similar inhibition of cell migration and invasion by synthetic MMP inhibitors, as reported previously $(2,5,6)$ and confirmed here, implies that these effects of TIMPs are mediated indirectly by inhibition of MMPs. Experiments in other systems have shown that TIMP-1 can suppress migration, invasion, and metastasis of cancer cells $(36,37,38)$. Together, these data indicate that TIMPs probably act generally to reduce local matrix destruction and invasion by inhibition of MMPs.

Overexpression of TIMP-1 had no effect on SMC number or BrdU incorporation compared with controls over the time course of the experiment, even with recombinant TIMP- 1 levels at $2800 \pm 300 \mathrm{ng}$ total TIMP- 1 . This result contrasts with one aspect of the work of Forough et al. (35), who reported that a clone of rat SMC retrovirally engineered to express an apparently much lower level of baboon TIMP-1 had a slower growth 

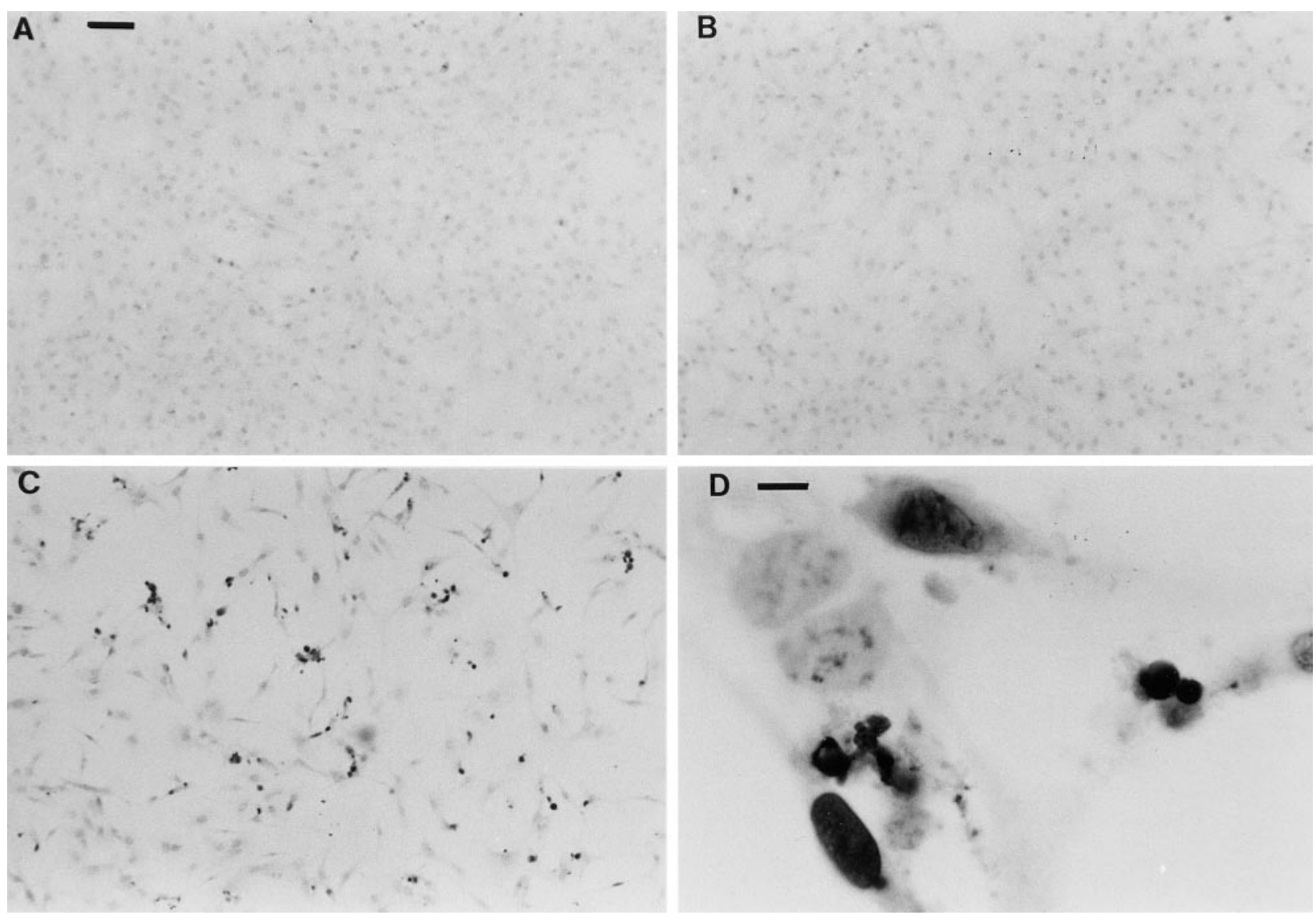

Figure 6. ISEL of DNA. SMC were infected and assessed for the presence of nicked DNA $42 \mathrm{~h}$ after infection. $(A)$ Uninfected control; $(B)$ RAd66 300 pfu/cell; ( $C$ and $D$ ) RAdTIMP-3 infected. Dark nuclei represent ISEL-positive nuclei; light-colored nuclei are negative. ( $A-C)$ Bar, $100 \mu \mathrm{m}$. (D) Bar, $10 \mu \mathrm{m}$. These data are representative of three experiments.

rate than control clones. However, in apparent contradiction, they (35) found no effect on proliferative indices in transduced and untransduced cells when the TIMP-1-overexpressing cells were used to seed injured rat vascular tissues in vivo. The reduced proliferation may therefore reflect clonal variation rather than increased TIMP-1 expression.

Overexpression of TIMP-2 inhibited both the increase in SMC numbers and BrdU-labeling, effects that have not been reported previously. No visible cell death accompanied the reduction in SMC numbers, indicating a specific effect of TIMP-2 on cell proliferation. Exogenous TIMP-2 did not reproduce the effect of RAdTIMP-2 infection, suggesting that the antiproliferative effect may be restricted to those cells that secrete high levels of TIMP-2. Although TIMP-2 has several functions including preferential binding to pro-MMP-2 and inhibition of MT-MMPs that distinguish it from TIMP-1, the results with synthetic inhibitors indicate that its effects on proliferation are likely to be independent of inhibition of MMPs. Indeed, TIMP-2 inhibits proliferation of microvascular endothelial cells induced by basic fibroblast growth factor through a mechanism independent of protease inhibitory activity (37). Transduction of TIMP-2 inhibits invasion and tumor volume of tumorigenic rat embryo fibroblasts in vivo (39), reduces melanoma growth in vivo (40), and affects the adhesive and spreading properties of melanoma cells (41), indicating that TIMP-2 can effect invasive and proliferative phenotypes of tu- mor cells. In some other cell systems, TIMP-2 can promote cell proliferation (26), but our data in SMC does not show this effect.

The most novel and important findings of our study are that TIMP-3 overexpression in SMC reduced cell number, induced DNA synthesis, elevated the number of cells in S/G2M phases of the cell cycle, and induced apoptotic cell death. Induction of cell death by adding exogenous TIMP-3 to uninfected cultures, and the finding that RAdTIMP-3-infected SMC caused apoptosis of neighboring uninfected cells (A.H. Baker and A.C. Newby, unpublished observations) indicates that a bystander effect occurs. Moreover, these effects are not confined to SMC, because adenoviral-mediated overexpression of TIMP-3 also promotes apoptosis of Hela cells in vitro (A.H. Baker and A.C. Newby, unpublished observations). The finding that TIMP-3 induces apoptosis obtains some support from previous experiments. Yang and Hawkes (42) showed that precoating plates with chicken TIMP-3 induces DNA synthesis in growth-retarded, nontransformed chicken embryonic fibroblasts. They also reported that it mediates detachment of transformed cells from their extracellular matrix, although by what mechanism was not elucidated. Furthermore, TIMP-3 overexpression in stable transfectants of colon carcinoma cells results in suspension cell death, although in this case it is mimicked by synthetic MMP inhibitors (43).

The effects of TIMP-3 on S-phase entry and apoptosis ob- 
A

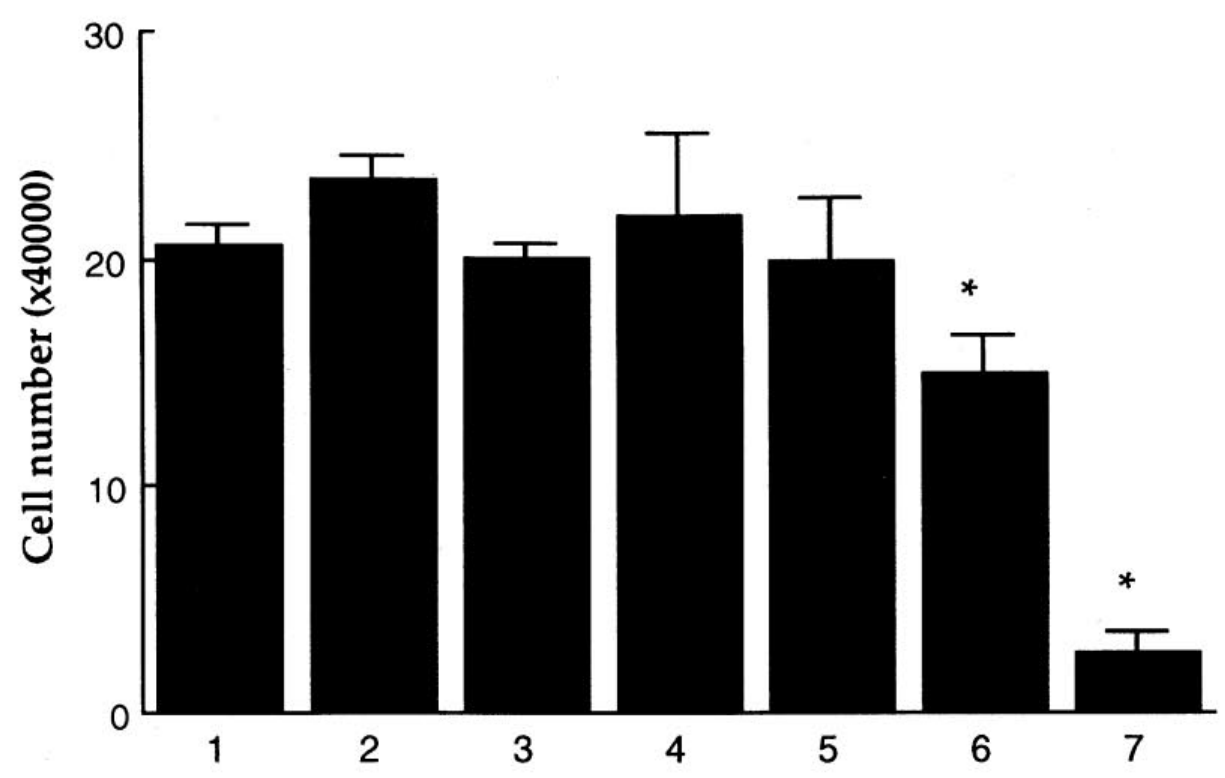

B

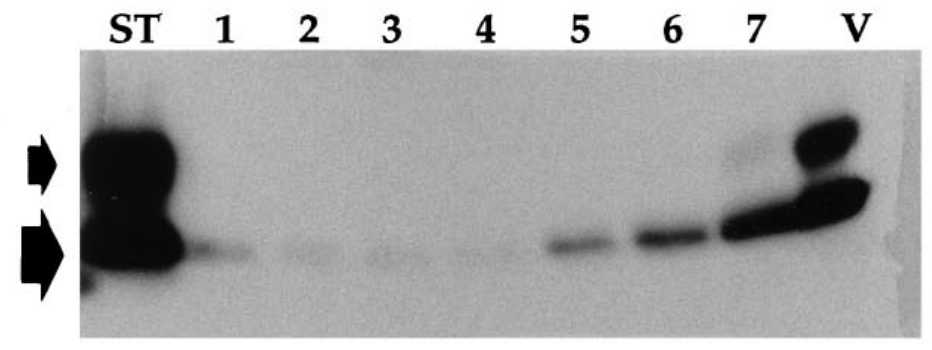

C
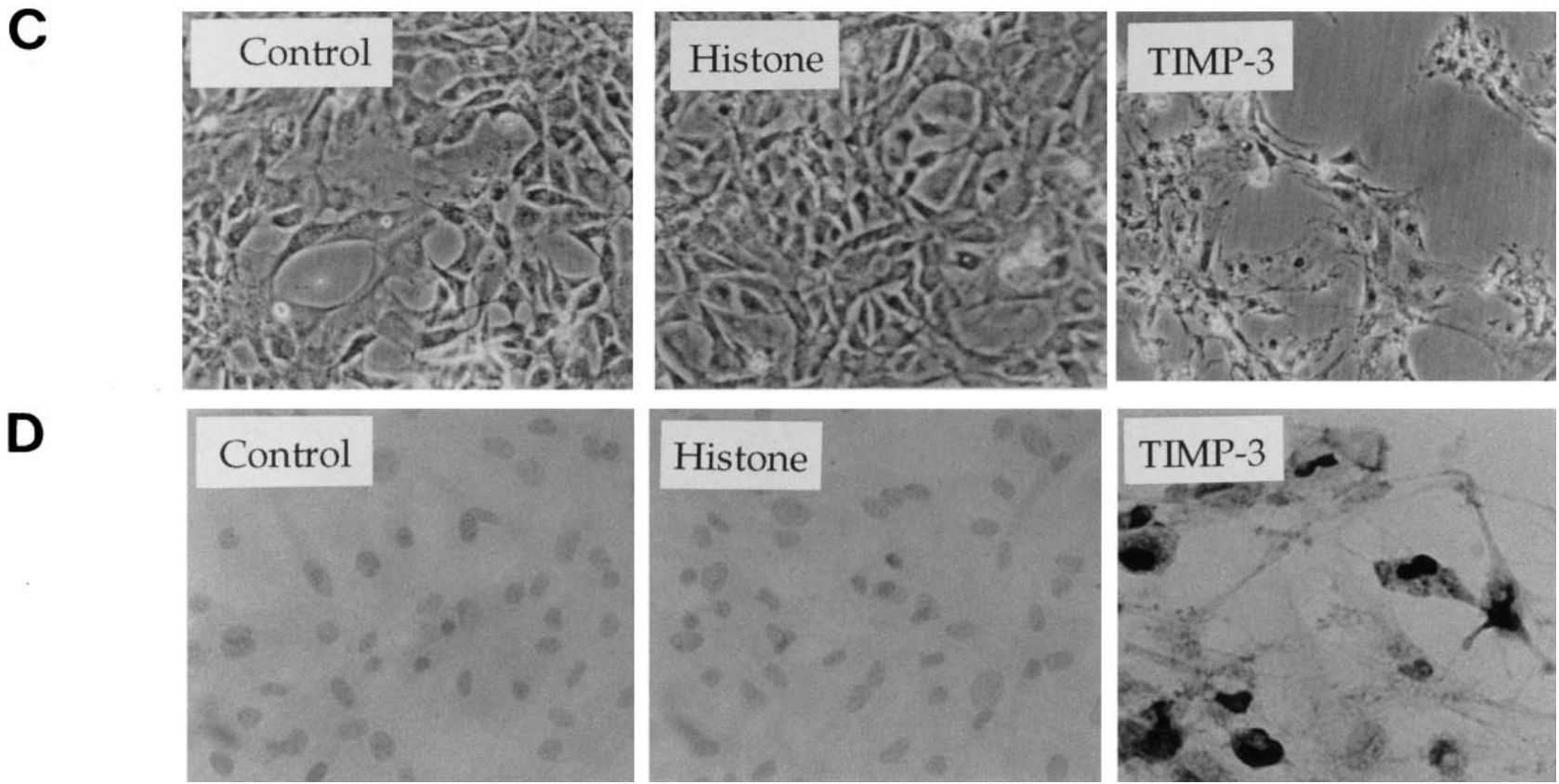

Figure 7. Induction of cell death induced by exogenous TIMP-3. Recombinant human TIMP-3 was added to cultures of rat SMC and analyzed for cell death. (A) Cell number $90 \mathrm{~h}$ after addition. (B) Western blot analysis of total cell lysates for TIMP-3. (1) Vehicle control; (2-4) 1, 2.5, and $5 \mu \mathrm{g}$ of histone, respectively; (5-7) $1,2.5$, and $5 \mu \mathrm{g}$ of TIMP-3, respectively (applicable to both $A$ and $B$ ). ${ }^{*} P<0.05$ for TIMP-3 vs. histone controls. (B) Standard $(S T)$ and RAdTIMP-3-treated cell lysate $(V)$ are indicated. The large arrow represents the unglycosylated form of TIMP-3, and the small arrow represents the glycosylated form. $(C)$ Phase contrast photographs of control- (vehicle), histone- $(5 \mu \mathrm{g})$ and TIMP-3- $(5 \mu \mathrm{g})$ treated cultures $90 \mathrm{~h}$ after addition. $(D)$ ISEL for control $(1.3 \pm 0.5 \%$ positive), histone $(1.1 \pm 0.8 \%$ positive), and TIMP-3 ( $38 \pm 3.5 \%$ positive, $P<$ 0.05 vs. control and histone, $n=3)$. These data are representative of two experiments. 


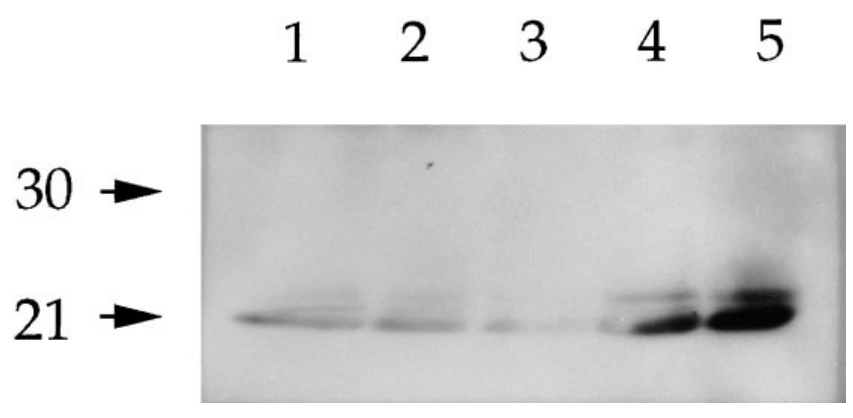

Figure 8. Induction of WAF1 by TIMP-3 in SMC. Cells from uninfected, RAd66-infected, and RAdTIMP-3-infected cultures were analyzed for WAF1 expression by Western blot analysis. (1) Uninfected; (2) RAd66 100 pfu/cell; (3) RAd66 300 pfu/cell; (4) RAdTIMP-3 100 pfu/cell; (5) RAdTIMP-3 300 pfu/cell. Molecular weight standards are indicated. Lanes were loaded equally for number of cells. These data are representative of two experiments.

served in our study confirm a close association between TIMP-3 and the cell cycle status of SMC. Wick et al. (44) reported that mRNA expression of the endogenous TIMP-3 gene is regulated by the cell cycle in fibroblasts and HL60 cells. TIMP-3 transcription is also induced in quiescent rabbit SMC stimulated into the cell cycle, in contrast to TIMP-1 and -2 (34). Furthermore, we showed that TIMP-3 overexpression induces expression of the cyclin-dependent kinase inhibitor WAF1. This $21-\mathrm{kD}$ protein has previously been shown to be induced in response to P-53 overexpression and subsequent apoptotic death of cancer cell lines and SMC in vitro $(45,46,47)$. Induction of WAF1 provides additional evidence for activation of intracellular cell cycle regulatory mechanisms by overexpression of TIMP-3.

In considering possible pathogenic roles for TIMP-3induced apoptosis, high levels of TIMP-3 mRNA have been detected in human breast cancer and in metastatic melanoma $(14,48)$, and may contribute to the high rate of apoptosis in these tumors. Increased expression of mRNA for TIMP-3 has been associated with retinas affected by simplex retinitis pigmentosa (49). Furthermore, mutations in the TIMP-3 gene leading to increased immunoreactive protein levels occur in the inherited disorder Sorsby's fundus dystrophy $(50,51)$. TIMP-3-mediated apoptosis may be central to these pathologies, although this possibility remains to be demonstrated.

Adenovirus-mediated overexpression of TIMPs may be useful as gene therapy for vascular disease for a number of reasons. First, the TIMPs are low molecular weight secreted proteins, and a bystander effect can occur. Second, inhibition of SMC invasion achieved by overexpressing TIMPs is highly efficient. Third, additional inhibition of SMC proliferation is achieved with TIMP-2. Gene transfer of TIMP-3 may also be beneficial, but in different circumstances. Induction of cell death for treatment of cancer by TIMP-3 overexpression may be a suitable strategy.

In summary, our studies clearly demonstrate similar and diverse effects evoked by overexpression of individual TIMPs. These results have important implications for their role in vascular biology and their potential application in gene therapy.

\section{Acknowledgments}

The authors wish to thank J.L. Johnson and C. Keen for technical assistance, G. Murphy (Strangeways Research Labs) for advice and recombinant TIMP-3, and Roche Products Limited (Welwyn Garden City, Herts, United Kingdom) for the synthetic MMP inhibitor.

This work was funded by the Medical Research Council for Great Britain and the British Heart Foundation.

\section{References}

1. Birkedal-Hansen, H., W.G.I. Moore, M.K. Bodden, L.J. Windsor, B. Birkedal-Hansen, A. DeCarlo, and J.A. Engler. 1993. Matrix metalloproteinases: a review. Crit. Rev. Oral Biol. Med. 4:197-250.

2. Southgate, K.M., M. Davies, R.F.G. Booth, and A.C. Newby. 1992. Involvement of extracellular matrix degrading metalloproteinases in rabbit aortic smooth muscle cell proliferation. Biochem. J. 288:93-99.

3. George, S.J., A.B. Zaltsman, and A.C. Newby. 1997. Surgical preparative injury and neointima formation increase MMP-9 expression and MMP-2 activation in human saphenous vein. Cardiovasc. Res. 33:447-459.

4. Pauly, R.R., A. Passaniti, C. Bilato, R. Monticone, L. Cheng, N. Papadopoulos, Y.A. Gluzband, L. Smith, C. Weinstein, E.G. Lakatta, and M.T. Crow. 1994. Migration of cultures vascular smooth muscle cells through a basement membrane barrier requires type IV collagenase activity and is inhibited by cellular differentiation. Circ. Res. 75:41-54.

5. Bendeck, M.P., N. Zempo, A.W. Clowes, R.E. Galardy, and M.A. Reidy. 1994. Smooth muscle cell migration and matrix metalloproteinase expression after arterial injury in the rat. Circ. Res. 75:539-545.

6. Bendeck, M.P., C. Irvin, and M.A. Reidy. 1996. Inhibition of matrix metalloproteinase activity inhibits smooth muscle cell migration but not neointimal thickening after arterial injury. Circ. Res. 78:38-43.

7. Zempo, N., R.D. Kenagy, T. Au, M. Bendeck, M.M. Clowes, M.A. Reidy, and A.W. Clowes. 1994. Matrix metalloproteinases of vascular wall cells are increased in balloon-injured rat carotid. J. Vasc. Surg. 20:209-217.

8. Southgate, K., M. Fisher, A. Banning, V. Thurston, A.H. Baker, R Fabunmi, P. Groves, M. Davies, and A.C. Newby. 1996. Upregulation of basement membrane degrading metalloproteinase secretion after balloon injury of pig carotid arteries. Circ. Res. 79:1177-1187.

9. Southgate, K., M. Izzat, D. Knight, and G.D Angelini. 1995. Up regulation of basement membrane degrading gelatinases in pig saphenous vein grafts. Br. Heart J. 73(Suppl. 3):46.

10. Galis, Z.S., G.K. Sukhova, M.W. Lark, and P. Libby. 1994. Increased expression of matrix metalloproteinases and matrix degrading activity in vulnerable regions of human atherosclerotic plaques. J. Clin. Invest. 94:2493-2503.

11. Li, Z., L. Li, R. Zielke, L. Cheng, R. Xiao, M.T. Crow, W.G. StetlerStevenson, J. Froehlich, and E.G. Lakatta. 1996. Increased expression of 72-kd type IV collagenase (MMP-2) in human aortic atherosclerotic lesions. Am. J. Pathol. 148:121-128.

12. Docherty, A.J.P., A. Lyons, B.J. Smith, E.M. Wright, P.E. Stephens, T.J.R. Harris, G. Murphy, and J.J. Reynolds. 1985. Sequence of human tissue inhibitor of metalloproteinases and its identity to erythroid-potentiating activity. Nature. 318:66-69.

13. Stetler-Stevenson, W.G., P.D. Brown, M. Onisto, A.T. Levy, and L.A. Liotta. 1990. Tissue inhibitor of metalloproteinases-2 (TIMP-2) mRNA expression in tumor cell lines and human tumor tissues. J. Biol. Chem. 265:1393313938.

14. Uria, J.A., A.A. Ferrando, G. Velasco, J.M.P. Freije, and C. LopezOtin. 1994. Structure and expression in breast tumors of human TIMP-3, a new member of the metalloproteinase inhibitor family. Cancer Res. 54:2091-2094.

15. Leco, K.J., S.S. Apte, G.T. Taniguchi, S.P. Hawkes, R. Khokha, G.A. Schultz, and D.R. Edwards. 1997. Murine tissue inhibitor of metalloproteinases-4 (Timp-4): CDNA isolation and expression in adult mouse tissues. FEBS Lett. 401:213-217.

16. Leco, K.J., R. Khokha, N. Pavloff, S.P. Hawkes, and D.R. Edwards. 1994. Tissue inhibitor of metalloproteinases-3 (TIMP-3) is an extracellular matrix-associated protein with a distinctive pattern of expression in mouse cells and tissues. J. Biol. Chem. 269:9352-9360.

17. Willenbrock, F., and G. Murphy. 1994. Structure-function relationships in the tissue inhibitors of metalloproteinases. Am. J. Respir. Crit. Care Med. 150:S165-S170.

18. Howard, E.W., E.C. Bullen, and M.J. Banda. 1991. Preferential inhibition of 72- and 92-kDa gelatinases by tissue inhibitor of metalloproteinases-2.J. Biol. Chem. 266:13070-13075.

19. Ward, R.V., S.J. Atkinson, P.M. Slocombe, A.J.P. Docherty, J.J. Reynolds, and G. Murphy. 1991. Tissue inhibitor of metalloproteinases-2 inhibits the activation of $72 \mathrm{kDa}$ progelatinase by fibroblast membranes. Biochem. Biophys. Acta. 1079:242-246.

20. Goldberg, G.I., B.L. Marmer, G.A. Grant, A.Z. Eisen, S. Wilhelm, and C. He. 1989. Human $72 \mathrm{~K}$ type IV collagenase forms a complex with a tissue in- 
hibitor of metalloproteases designated TIMP-2. Proc. Natl. Acad. Sci. USA. 86: 8207-8211.

21. Fridman, R., T.R. Fuerst, R.E. Bird, M. Hoyhtya, M. Oelkuct, S. Kraus, D. Komarek, L.A. Liotta, M.L. Berman, and W.G. StetlerStevenson. 1992. Domain-structure of human $72-\mathrm{Kda}$ gelatinase type-IV collagenase characterization of proteolytic activity and identification of the tissue inhibitor of metalloproteinase-2 (TIMP-2) binding regions. J. Biol. Chem. 267:15398-15405.

22. Murphy, G., F. Willenbrock, R.V. Ward, M.I. Cockett, D. Eaton, and A.J.P. Docherty. 1992. The C-terminal domain of $72 \mathrm{kDa}$ gelatinase A is not required for catalysis, but is essential for membrane activation and modulates interactions with tissue inhibitors of metalloproteinases. Biochem. J. 283:637-641.

23. Strongin, A.Y., I. Collier, B.L. Bannikov, G.A. Grant, and G.I. Goldberg. 1995. Mechanism of cell surface activation of $72 \mathrm{kDa}$ type IV collagenase. J. Biol. Chem. 270:5331-5338.

24. Will, H.W., S.J. Atkinson, G.S. Butler, B. Smith, and G. Murphy. 1996. The soluble catalytic domain of membrane type 1 metalloproteinase cleaves the propeptide of progelatinase A and initiates autoproteolytic activation. J. Biol. Chem. 271:17119-17123.

25. Murphy, A.N., E.J. Unsworth, and W.G. Stetler-Stevenson. 1993. Tissue inhibitor of metalloproteinases-2 inhibits bFGF-induced human microvascular endothelial cell proliferation. J. Cell. Physiol. 157:351-358.

26. Hayakawa, T., K. Yamashita, E. Ohuchi, and A. Shinagawa. 1994. Cell growth-promoting activity of tissue inhibitor of metalloproteinases-2 (TIMP-2). J. Cell Science. 107:2373-2379.

27. Graham, F., J. Smiley, C. Russell, and R. Nairn. 1977. Characterization of a human cell line transformed by DNA from human adenovirus type $5 . J$. Gen. Virol. 36:59-72.

28. Bennett, M.R., S. Anglin, J.R. McEwan, R. Jagoe, A.C. Newby, and G.I. Evan. 1994. Inhibition of vascular smooth muscle cell proliferation in vitro and in vivo by c-myc antisense oligodeoxynucleotides. J. Clin. Invest. 93:820-828.

29. Wilkinson, G.W.G., and A. Akrigg. 1992. Constitutive and enhanced expression from the CMV major IE promoter in a defective adenovirus vector. Nucleic Acids Res. 20:2233-2239.

30. Baker, A.H., G.W.G. Wilkinson, R.M. Hembry, G. Murphy, and A.C. Newby. 1996. Development of recombinant adenoviruses that drive high level expression of the human metalloproteinase-9 and tissue inhibitor of metalloproteinase-1 and -2 genes: characterization of their infection into rabbit smooth muscle cells and human MCF-7 adenocarcinoma cells. Matrix Biol. 15:383-395.

31. Sanger, F., S. Nicklen, and A.R. Coulson. 1977. DNA sequencing with chain-terminating inhibitors. Proc. Natl. Acad. Sci. USA. 74:5463-5467.

32. McGrory, W.J., D.S. Bautista, and F.L. Graham. 1988. A simple technique for the rescue of early region 1 mutations into infectious human adenovirus type 5. Virology. 163:614-617.

33. Laemmli, U.K. 1970. Cleavage of structural proteins during assembly of the head of bacteriophage T4. Nature. 227:680-685.

34. Fabunmi, R.P. A.H. Baker, E.J. Murray, R.F.G. Booth, and A.C. Newby. 1996. Divergent regulation by growth-factors and cytokines of $95-\mathrm{kDa}$ and 72-kDa gelatinases and tissue inhibitors of metalloproteinase-1, -2 and -3 in rabbit aortic smooth muscle cells. Biochem. J. 315:335-342.

35. Forough, R., N. Koyama, D. Hasenstab, H. Lea, M. Clowes, S.T. Nikkari, and A.W. Clowes. 1996. Overexpression of tissue inhibitor of matrix metalloproteinase-1 inhibits vascular smooth muscle cell functions in vitro and in vivo. Circ. Res. 79:812-820.

36. Walther, S.E., and D. Denhardt. 1996. Directed mutagenesis reveals that two histidines in tissue inhibitor of metalloproteinase- 1 are each essential for the suppression of cell migration, invasion, and tumorigenicity. Cell Growth Differ. 7:1579-1588.

37. Watanabo, M., Y. Takahashi, T. Ohta, M. Mai, T. Sasaki, and M. Selki. 1996. Inhibition of metastasis in human gastric cancer cells transfected with tissue inhibitor of metalloproteinase 1 gene in nude mice. Cancer. 77:1676-1680.

38. Martin, D., U. Ruther, O. Sanchez-Sweatman, F. Orr, and R. Khokha. 1996. Inhibition of SV40 T antigen-induced hepatocellular carcinoma in TIMP-1 transgenic mice. Oncogene. 13:569-576.

39. Imren, S., D.B. Kohn, H. Shimada, L. Blavier, and Y.A. DeClerck. 1996. Overexpression of tissue inhibitor of metalloproteinases- 2 by retroviral-mediated gene transfer in vivo inhibits tumor growth and invasion. Cancer Res. 56: 2891-2895.

40. Montgomery, A.M.P., B.M. Mueller, R.A. Reisfeld, S.M. Taylor, and Y.A. DeClerck. 1994. Effect of tissue inhibitor of the matrix metalloproteinase expression on the growth and spontaneous metastasis of a human melanoma cell line. Cancer Res. 54:5467-5473.

41. Ray, J.M., and W.G. Stetler-Stevenson. 1995. Gelatinase A directly modulates melanoma cell adhesion and spreading. EMBO J. 14:908-917.

42. Yang, T.-T., and S.P. Hawkes. 1992. Role of the 21-kDa protein TIMP-3 in oncogenic transformation of cultured chicken embryo fibroblasts. Proc. Natl. Acad. Sci. USA. 89:10676-10680.

43. Bian, J.H., Y.L. Wang, M.R. Smith, H. Kim, C. Jacobs, J. Jackman, H.F Kung, N.H. Colburn, and Y. Sun. 1996. Suppression of in vivo tumor-growth and induction of suspension cell death by tissue inhibitor of metalloproteinases (TIMP)-3. Carcinogenesis. 17:1805-1811.

44. Wick, M. C. Bürger, S. Brüsselbach, F.C. Lucibello, and R. Müller. 1994. A novel member of human tissue inhibitor of metalloproteinases (TIMP) gene family is regulated during G1 progression, mitogenic stimulation, differentiation and senescence. J. Biol. Chem. 29:18953-18960.

45. El-Deiry, W.S., J. Wade Harper, P.M. O'Connor, V.E. Velculescu, C.E. Canman, J. Jackman, J.A. Pietenpol, M. Burrell, D.E. Hill, Y. Wang, et al. 1994. $W A F 1 / C I P 1$ is induced in p53-mediated G1 arrest and apoptosis. Cancer Res. 54:1169-1174

46. Katayose, D., R. Wersto, K. Cowan, and P. Seth. 1995. Consequences of p53 gene expression by adenovirus vector on cell cycle arrest and apoptosis in human aortic vascular smooth muscle cells. Biochem. Biophys. Res. Commun. 215:446-451.

47. Katayose, D., R. Wersto, K. Cowan, and P. Seth. 1995. Effects of a recombinant adenovirus expressing WAF1/Cip1 on cell growth, cell cycle and apoptosis. Cell Growth Differ. 6:1207-1212.

48. Silbiger, S.M., V.L. Jacobsen, R.L. Cupples, and R.A Koski. 1994. Cloning of cDNAs encoding human TIMP-3, a novel member of the tissue inhibitor of metalloproteinase family. Gene. 141:293-297.

49. Jones, S., C. Jomary, and M. Neal. 1994. Expression of TIMP3 mRNA is elevated in retinas affected by simplex retinitis-pigmentosa. FEBS Lett. 352: 171-174.

50. Weber, B.H.F., G. Vogt, R.C. Pruett, H. Stöhr, and U. Felbor. 1994 Mutations in the tissue inhibitor of metalloproteinases-3 (TIMP-3) in patients with Sorsby's fundus dystrophy. Nat. Genet. 8:352-355.

51. Fariss, R.N., S.S. Apte, B.R. Olsen, K. Iwata, and A.H. Milham. 1997. Tissue inhibitor of metalloproteinase-3 is a component of Bruch's membrane of the eye. Am. J. Pathol. 150:323-328. 